Portland State University

PDXScholar

Environmental Science and Management

Faculty Publications and Presentations

4-2010

\title{
Predicting Global Change Effects on Forest Biomass and Composition in South-Central Siberia
}

\author{
Eric J. Gustafson \\ US Department of Agriculture Forest Service \\ Anatoly Z. Shvidenko \\ International Institute for Applied Systems Analysis \\ Brian R. Sturtevant \\ US Department of Agriculture Forest Service \\ Robert M. Scheller \\ Portland State University
}

Follow this and additional works at: https://pdxscholar.library.pdx.edu/esm_fac

Part of the Environmental Sciences Commons, and the Forest Biology Commons Let us know how access to this document benefits you.

\section{Citation Details}

Eric J. Gustafson, Anatoly Z. Shvidenko, Brian R. Sturtevant, and Robert M. Scheller 2010. Predicting global change effects on forest biomass and composition in south-central Siberia. Ecological Applications 20:700-715.

This Article is brought to you for free and open access. It has been accepted for inclusion in Environmental Science and Management Faculty Publications and Presentations by an authorized administrator of PDXScholar. Please contact us if we can make this document more accessible: pdxscholar@pdx.edu. 


\title{
Predicting global change effects on forest biomass and composition in south-central Siberia
}

\author{
Eric J. Gustafson, ${ }^{1,4}$ Anatoly Z. Shvidenko, ${ }^{2}$ Brian R. Sturtevant, ${ }^{1}$ and Robert M. Scheller ${ }^{3}$ \\ ${ }^{1}$ Institute for Applied Ecosystem Studies, USDA Forest Service, Northern Research Station, 5985 Highway K, \\ Rhinelander, Wisconsin 54501 USA \\ ${ }^{2}$ International Institute for Applied Systems Analysis, Schlossplatz 1, A-2361 Laxenburg, Austria \\ ${ }^{3}$ Conservation Biology Institute, 136 SW Washington, Suite 202, Corvallis, Oregon 97333 USA
}

\begin{abstract}
Multiple global changes such as timber harvesting in areas not previously disturbed by cutting and climate change will undoubtedly affect the composition and spatial distribution of boreal forests, which will, in turn, affect the ability of these forests to retain carbon and maintain biodiversity. To predict future states of the boreal forest reliably, it is necessary to understand the complex interactions among forest regenerative processes (succession), natural disturbances (e.g., fire, wind, and insects), and anthropogenic disturbances (e.g., timber harvest). We used a landscape succession and disturbance model (LANDIS-II) to study the relative effects of climate change, timber harvesting, and insect outbreaks on forest composition, biomass (carbon), and landscape pattern in south-central Siberia. We found that most response variables were more strongly influenced by timber harvest and insect outbreaks than by the direct effects of climate change. Direct climate effects generally increased tree productivity and modified probability of establishment, but indirect effects on the fire regime generally counteracted the direct effects of climate on forest composition. Harvest and insects significantly changed forest composition, reduced living aboveground biomass, and increased forest fragmentation. We concluded that: (1) Global change is likely to significantly change forest composition of south-central Siberian landscapes, with some changes taking ecosystems outside the historic range of variability. (2) The direct effects of climate change in the study area are not as significant as the exploitation of virgin forest by timber harvest and the potential increased outbreaks of the Siberian silk moth. (3) Novel disturbance by timber harvest and insect outbreaks may greatly reduce the aboveground living biomass of Siberian forests and may significantly alter ecosystem dynamics and wildlife populations by increasing forest fragmentation.
\end{abstract}

Key words: aboveground live biomass; boreal forests; climate; fire; forest fragmentation; global change; insect disturbance; LANDIS-II; timber harvest.

\section{INTRODUCTION}

Global climate and land use changes are having multiple effects on forests worldwide. These effects are complex and interacting, and are therefore difficult to predict. For example, climate change will likely affect productivity, species range distributions, and natural disturbance regimes, and the magnitude of these effects is greater at high latitudes (IPCC 2007). Land use and timber harvest regimes are changing, with some previously uncut areas of the globe now experiencing harvesting (e.g., Siberia) and other areas that previously experienced intensive harvesting are now being cut at greatly reduced rates (e.g., Great Lakes region of North America). These components of global change will undoubtedly affect the composition and spatial distribution of forests, which will in turn affect the ability of

Manuscript received 24 September 2008; revised 16 June 2009; accepted 23 June 2009. Corresponding Editor: D. McKenzie.

${ }^{4}$ E-mail: egustafson@fs.fed.us these forests to retain carbon and maintain biodiversity. However, the multi-scaled interactions among climate change, disturbance regimes, and land use change make it difficult to predict key ecosystem characteristics except by coarse, generalized estimates.

The forested regions of Siberian Russia are vast and contain about a quarter of the world's forests that have not experienced harvesting (Dirk et al. 1997). However, many Siberian forests are facing twin pressures of rapidly changing climate and increasing timber harvest activity. Mean temperatures have risen significantly over the past 40 years, and this trend is expected to continue, while precipitation trends are unclear, with a statistically insignificant negative trend during the growing season (Vaschuk and Shvidenko 2006). The frontier of timber harvest is pushing into previously uncut areas. Such changes may have substantial but as yet unknown effects on Siberian forests (Shvidenko et al. 2007a).

Climate change will have a broad array of direct effects on Siberian forests and forest dynamics. Alterations in the means and seasonal distribution of 
temperatures, precipitation, and solar irradiation will alter the net primary productivity (NPP) of extant species and therefore alter their competitive fitness (Peng and Apps 1999, Pan et al. 2006, Xu et al. 2007). Generally, it is expected that overall NPP will increase as temperatures increase, increasing the rate of aboveground carbon sequestration (Peng and Apps 1999, Xu et al. 2007). However, diseases, pests, and water stress may tend to reduce productivity with warmer temperatures (IPCC 2007). Likewise, the rate of decomposition will change as a function of climate, dependent upon soil texture and the portion of the material (woody debris or soil carbon) that is labile vs. recalcitrant (Trofymow et al. 2002). If the rate of decomposition increases, net $N$ mineralization will increase, further increasing NPP (Peng and Apps 1999). Because tree species have unique physiological and ecological adaptations to environmental conditions, these changes may alter competitive relationships among species and affect population abundance, forest composition, and may shift species range limits.

Climate change will also indirectly alter forest composition and dynamics through effects on disturbance regimes (Dale et al. 2001). In boreal forests, dominant disturbances are currently fire (Johnson et al. 1998) and insects (Nealis and Regniere 2004). The incidence and severity of fires is likely to increase because of longer and warmer summers (Litkina 2003, Efremov and Shvidenko 2004, Goldammer et al. 2004). Insects may become more active and expand their range into areas where they are currently cold-limited (Bale et al. 2002, Logan et al. 2003). These disturbances may have a multiplicative effect if increased tree mortality caused by insect pests generates favorable conditions for ignitions or larger and/or more intense fires. The anthropogenic disturbance of timber harvesting in Siberia is primarily by clear-cutting (with seed trees), and these harvests will alter the amount and spatial distribution of successional stages, woody biomass, and forest composition. Multiple forest openings will increase fragmentation and its associated effects on biodiversity, and the building of roads may increase human access and fire ignition rates.

Boreal forests currently sequester a large share of the world's terrestrial carbon (Melillo et al. 1993), and climate change and anthropogenic disturbance have the potential to significantly alter the carbon fluxes of these forests (Kurz and Apps 1999, Goodale et al. 2002, Euskirchen et al. 2006). There is a rapidly increasing worldwide interest in developing forest policy and management systems to maintain the productivity and ecological integrity of these ecosystems. However, boreal forested ecosystems feature complex interactions among forest regenerative processes (succession), natural disturbances (e.g., fire, wind, and insects) and anthropogenic disturbances (e.g., timber harvest). It is difficult to make reliable projections of the effects of climate change and policy options in the face of such complexity. Simulation models offer methods to explore alternative future scenarios as a function of underlying drivers of change. LANDIS-II is a forest landscape disturbance and succession model that independently models multiple ecological and anthropogenic processes so that interactions of these processes are an emergent property of the simulations (Mladenoff 2004). The model projects many important characteristics related to the ecological functioning of forested landscapes over long time periods such as tree and age class composition, amount and spatial arrangement of living and dead biomass, and conditions leading to forest fragmentation. LANDIS-II can be linked to the outputs of global circulation models (GCMs) to allow climate change to interact with landscape processes in the simulation environment.

The objectives of this study were to (1) quantify the ecology (disturbance and succession) and management of a Siberian landscape that has not been described satisfactorily in the English language literature, (2) parameterize and run LANDIS-II for current climatic conditions on this landscape, and (3) conduct a factorial experiment to determine the relative effects of climate change, timber harvesting and insect outbreaks on forest composition, biomass (carbon), and landscape pattern.

\section{Methods}

\section{Description of the Siberian study area}

The 316 527-ha study area is situated in the northeastern part of the Severny leshoz (i.e., Northern forest enterprise) near the city of Ust-Ilimsk (Fig. 1). It is located in the Chuno-Angarsky sub-ecoregion at the boundary between the southern and middle taiga bioclimatic zones (see Plate 1). Soils are fairly homogeneous and are dominated by relatively deep and fertile Sod-Podzols. The study area is primarily a hilly plain ranging between $250 \mathrm{~m}$ and $450 \mathrm{~m}$ elevation, with the Angara river valley located along the western edge. Forests of the region are dominated by Scots pine (Pinus sylvestris) and secondary soft-hardwood deciduous (Betula pendula, Populus tremula) forests. Climate is continental, with long and severe winters (mean January temperature $=-29^{\circ} \mathrm{C}$ ) and short, but warm (mean July temperature $=17^{\circ} \mathrm{C}$ ) and humid summers. Precipitation is $90 \mathrm{~cm}$ annually, with two-thirds falling from April to September (Vaschuk and Shvidenko 2006). Permafrost is rare in the study area, occurring only in small patches at the highest elevations. Mean temperature in the region rose $2^{\circ}-3.5^{\circ} \mathrm{C}$ during the last century, with an accelerating rate of change, while precipitation did not change significantly (Vaschuk and Shvidenko 2006). An ensemble of 16 coupled atmosphere-ocean GCMs running the A2 emission scenario predicted a temperature increase during the 21 st century for the region in the range of $4^{\circ}-$ $6^{\circ} \mathrm{C}$, with a much smaller increase in precipitation (Meleshko et al. 2008). Although the variability of forecasts among models was high, some trends were consistent: (1) winter temperatures (December- 


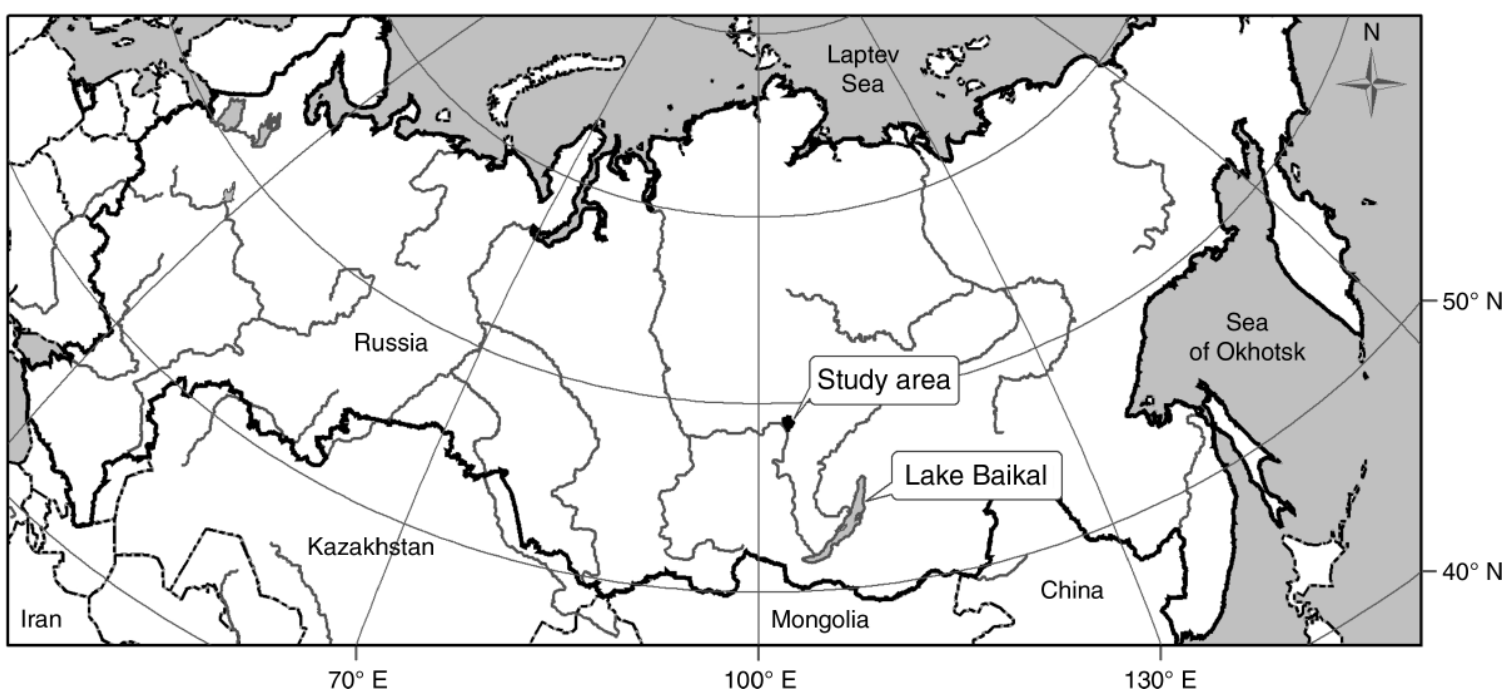

FIG. 1. Location of the study area, centered at $58.9^{\circ} \mathrm{N}, 103.0^{\circ} \mathrm{E}$.

February) will increase the most, as much as $10^{\circ} \mathrm{C}$ in northern Siberia, (2) spring and summer (March to August) temperatures will increase on average about $4^{\circ} \mathrm{C}$ to $4.5^{\circ} \mathrm{C}$, and (3) the increase in precipitation will not be as great as the increase in temperature.

The forests of the study area are comprised of seven dominant species (scientific names in Table 1). These species are commonly classified as dark conifers (Siberian spruce, Siberian fir, and stone pine or "cedar" as it is called in Russia, which is a five-needle pine with wingless seeds), light conifers (Scots pine and Siberian larch), and soft-hardwood deciduous. The age structure of these forests has been formed primarily by the fire regime, which is the dominant natural disturbance. The dark conifers are typically uneven aged $(>3$ age cohorts), usually succeeding the aspen-birch stands that establish following fire. Thirty percent of Scots pine and $\sim 70 \%$ of mature larch stands are relatively uneven aged (2-3 cohorts), a structure that develops when multiple surface fires kill ground vegetation and shrubs, allowing new cohorts to establish after each fire. All other stands are mostly even aged, being established after standreplacing fire or harvest. Fires are mostly of human origin, and because roads are poor, most fires are not suppressed and the size of fires can be quite large $(>500$ ha). Most (>90\%) fires are surface fires, but crown fires do occur (primarily in Scots pine stands), and are responsible for $17 \%$ of the total burned area. Light conifer stands regenerate readily after fire. Dark conifers stands usually regenerate to birch and aspen after fire, which is then followed by either spruce-fir or stone pine depending on moisture, nutrients, severity of the fire, and seed sources.

Large blowdown events (>50000 ha) are rare, but they do occur. For example, a wind storm on 16 July 2004 heavily damaged 78000 ha in a nearby area. The subsequent composition and age structure of stands depends on the extent of the mortality.

A major tree-killing insect, the Siberian silk moth (Dendrolimus sibiricus superanse), occurs in the region (Gninenko and Orlinskii 2002), but it rarely kills forests in the study area because of a relatively low abundance of stone pine and relatively cool and moist summers. However, outbreaks may increase in the study area if summers become warmer and the frequency of extreme cold events that kill overwintering individuals is reduced. The primary hosts are stone pine, fir, and spruce, but the larvae can feed on and kill all needleleaved species. The deciduous larch usually survives outbreaks, and is killed only after three successive years of defoliation. Outbreaks occur every 15-30 years, initiating in areas with high densities of older fir and stone pine stands (Kondakov 1974).

The forests in the study area are owned by the state and managed by the Severny leshoz, which is sanctioned by the state to conduct harvest and management activities. Much of the study area has never been harvested because of its remoteness. It was recently opened for timber production and will be completely accessible for harvest over the next two decades. The management regime is fairly homogeneous across the study area. The study area is divided into 4 to $8 \mathrm{~km}^{2}$ administrative units called kvartels, which are further subdivided into compartments (separate stands) with an average area of 20-25 ha. Harvest units (blocks) do not exceed 50 ha in size, and adjacent blocks are not harvested for at least three years. Riparian and ecologically sensitive areas are protected from industrial harvests.

\section{Simulation of current ecosystem dynamics using LANDIS-II}

We simulated forest landscape dynamics using the process-based, spatially dynamic model of forest suc- 
TABLE 1. Selected LANDIS (landscape succession and disturbance model) biomass succession parameters for south-central Siberia.

\begin{tabular}{|c|c|c|c|c|c|}
\hline Species & Common name & $\begin{array}{l}\text { Probability of } \\
\text { establishment }\end{array}$ & $\underset{\left(\mathrm{kg} \cdot \mathrm{ha}^{-1} \cdot \mathrm{yr}^{-1}\right)}{\operatorname{Maximum}}$ & $\begin{array}{c}\text { Woody decay } \\
\text { rate }(k)\end{array}$ & $\begin{array}{l}\text { Leaf decay } \\
\text { rate }(k)\end{array}$ \\
\hline \multicolumn{6}{|l|}{ Current climate } \\
\hline Picea obovata & Siberian spruce & 0.384 & 705 & 0.046 & 0.60 \\
\hline Abies sibirica & Siberian fir & 0.155 & 606 & 0.050 & 0.60 \\
\hline Larix sibirica & Siberian larch & 0.427 & 940 & 0.032 & 0.75 \\
\hline Pinus sylvestris & Scots pine & 0.395 & 660 & 0.040 & 0.60 \\
\hline Pinus sibirica & stone pine & 0.449 & 689 & 0.036 & 0.50 \\
\hline Betula pendula & white birch & 0.368 & 804 & 0.057 & 1.00 \\
\hline Populus tremula & quaking aspen & 0.186 & 745 & 0.065 & 1.00 \\
\hline \multicolumn{6}{|l|}{ Future climate } \\
\hline Picea obovata & Siberian spruce & 0.234 & 827 & 0.049 & 0.63 \\
\hline Abies sibirica & Siberian fir & 0.127 & 692 & 0.053 & 0.63 \\
\hline Larix sibirica & Siberian larch & 0.400 & 915 & 0.035 & 0.78 \\
\hline Pinus sylvestris & Scots pine & 0.507 & 824 & 0.043 & 0.63 \\
\hline Pinus sibirica & stone pine & 0.203 & 727 & 0.039 & 0.53 \\
\hline Betula pendula & white birch & 0.354 & 897 & 0.060 & 1.00 \\
\hline Populus tremula & quaking aspen & 0.234 & 795 & 0.068 & 1.00 \\
\hline
\end{tabular}

Notes: The complete parameter file is found in the Supplement. ANPP is aboveground net primary productivity. Decay rate $(k)$ was calcuted as DeadBiomass $(t+1)=$ DeadBiomass $(t) e^{-k}$. Future climate is as predicted by the Hadley GCM for the period $2080-$ 2099.

cession and disturbance, LANDIS-II (Scheller et al. 2007b). LANDIS-II consists of a core collection of libraries (Scheller and Domingo 2006) and a collection of optional extensions that represent the ecological processes of interest. LANDIS-II is derived from the LANDIS model (Mladenoff 2004) where the landscape is represented as a grid of interacting cells. Each cell may contain multiple species and each species can be represented by one or many age cohorts. Each cohort will establish and respond to disturbance as a function of its life history attributes (e.g., shade tolerance), and in the case of disturbance, its age. The primary model output is maps of forest conditions, including species, age classes, aboveground (living and dead), disturbance types, and their respective severities.

Spatial inputs for LANDIS-II take the form of raster maps (100-m cell size in this study) and include the land types (ecoregions), tree species cohorts initially found on each cell, and timber harvest management areas. Because the study area is relatively homogeneous with respect to abiotic conditions and disturbance regimes, a single land type was used. The initial map of tree species and cohorts was created from a digital stand map prepared for another study (Schmullius et al. 2003). The management area map delineated harvest and noharvest zones. No-harvest zones were a minor proportion of the study area and included low-productivity stands and riparian buffers between 100 and $1000 \mathrm{~m}$ wide adjacent to rivers and lakes, with the widest buffers located adjacent to the largest rivers.

We required six LANDIS-II extensions to simulate the ecological processes that determine the composition and landscape structure of the study area. Succession was simulated using Biomass Succession extension version 1.2 (Scheller and Mladenoff 2004). This extension calculates competition among cohorts, the increase of living biomass in cohorts of each tree species, and the gain and loss of woody and non-woody dead biomass using life history attributes (Table 1). Wind disturbance was simulated using Base Wind version 1.3 (Scheller et al. 2007a). This extension simulates cohort mortality caused by wind events, which kills older cohorts more readily than younger ones. We used estimates of the mean wind disturbance regime for a region that includes the study area (maximum, mean, and minimum wind event size equals 70000,7000 , and 20 ha, respectively; wind rotation period [time to disturb area equal to study area] is 1200 years). Tree cohort mortality caused by the Siberian silk moth was simulated using the Base BDA (Biological Disturbance Agent) extension version 1.1 (Sturtevant et al. 2004b). Fires were simulated using the Dynamic Fire System extension version 1.0 (Sturtevant et al. 2008). This extension simulates fire severity and spread based on previous LANDIS fire modules (e.g., Yang et al. 2004) and the Canadian Forest Fire Behavior Prediction System (Forestry Canada Fire Danger Group 1992) and the resulting cohort mortality. Fuel types as required by the fire extension were calculated by the Dynamic Fuels System extension version 1.0 (Shinneman et al. 2008). This extension translated LANDIS-II species-cohort information into Canadian Fire Behavior Prediction System fuel types (Forestry Canada Fire Danger Group 1992). Timber harvesting was simulated using the Biomass Harvest extension version 1.0 (Gustafson et al. 2000). This extension simulates removal of cohort biomass (and optional establishment by planting) caused by timber harvest activities and links to the fuel extension to account for logging slash. Each process was simulated using a 10year time step. All LANDIS-II parameter files can be accessed in the online Supplement. 
TABLE 2. Selected PnET parameters used to estimate maximum ANPP for the LANDIS-II biomass extension.

\begin{tabular}{lcccccccc}
\hline \hline \multicolumn{1}{c}{ Species } & $\begin{array}{c}\text { Foliar } \\
\text { nitrogen } \\
(\% \mathrm{~N})\end{array}$ & $\begin{array}{c}\text { Leaf mass } \\
\text { area } \\
\left(\mathrm{g} / \mathrm{m}^{2}\right)\end{array}$ & $\begin{array}{c}\text { Mean foliar } \\
\text { retention } \\
(\mathrm{yr})\end{array}$ & $\begin{array}{c}\text { GDD } \\
\text { to start } \\
\text { leafout }\end{array}$ & $\begin{array}{c}\text { GDD } \\
\text { to end } \\
\text { leafout }\end{array}$ & $\begin{array}{c}\text { GDD to } \\
\text { start wood } \\
\text { production }\end{array}$ & $\begin{array}{c}\text { GDD to } \\
\text { end wood } \\
\text { production }\end{array}$ & $\begin{array}{c}\text { Julian date } \\
\text { of latest } \\
\text { leaf drop } \dagger\end{array}$ \\
\hline Picea obovata & 1.0 & 180 & 7 & 150 & 331 & 331 & 1591 & 285 \\
Abies sibirica & 0.9 & 180 & 8 & 150 & 331 & 331 & 1591 & 285 \\
Pinus sylvestris & 0.95 & 210 & 6 & 292 & 624 & 331 & 1591 & 285 \\
Pinus sibirica & 0.9 & 210 & 8 & 292 & 624 & 331 & 1591 & 285 \\
Larix sibirica & 1.5 & 135 & 1 & 150 & 331 & 331 & 1591 & 288 \\
Betula pendula & 2.35 & 52 & 1 & 92 & 210 & 210 & 1591 & 276 \\
Populus tremula & 1.95 & 50 & 1 & 150 & 255 & 255 & 1586 & 268
\end{tabular}

Notes: PnET-II is a forest carbon and water balance model that can be used to predict how changes in climate affect the ANPP of tree species. Most other parameters took the generic conifer or deciduous values used by Ollinger and Smith (2005), except that, for larch (Larix sibirica), conifer values were used for canopy parameters and deciduous values for all others. GDD stands for growing degree-days (base $=0^{\circ} \mathrm{C}$ ).

$\dagger$ Day 1 of Julian date is January 1.

LANDIS-II was specifically designed to address climate change effects on forested ecosystems (Xu et al. 2007, 2009, Scheller and Mladenoff 2008), and therefore, climate parameters are used in the simulation of several ecological processes. Climate affects succession by modifying the probability of establishment $\left(P_{\text {est }}\right)$ and maximum aboveground net primary productivity (ANPP) for each species. Climate also affects fire and insect disturbance as described in the Simulation experiment section. Parameters for the current climate were based on a 21-year daily weather record from the city of Ust-Ilimsk during the period 1981-2001.

The biomass extension uses estimates of the maximum possible ANPP for each species to simulate growth and succession processes, and ANPP is expected to vary with climate. Because future ANPP cannot be measured empirically, we modeled ANPP using PnET-II version 4.1-1.2c (Aber et al. 1995) to generate comparable ANPP values for both current and future climates. PnET-II is a forest carbon and water balance model that can be used to predict how changes in climate (monthly means of surface temperature, precipitation, and photosynthetically active shortwave radiation) affect the ANPP of tree species. The relationships between ANPP and foliar nitrogen and leaf mass are robust across North America species (Ollinger and Smith 2005). PnET estimates of ANPP for each species under current climate were compared to empirical measurements of ANPP in the region around the study area (Shvidenko et al. 2007b). Assuming that discrepancies between estimated and observed ANPP was caused primarily by parameter error, PnET input parameters for only foliar nitrogen and leaf mass for each species were varied within empirical confidence limits to increase agreement (to within 4\%) of predictions with empirical estimates of ANPP under current climate, and the values used are shown in Table 2. To our knowledge, PnET has not previously been applied for Siberian species.

The probability of establishment for each species is also expected to vary with climate, and these were estimated using a simulation approach that used annual climate data and measures of species climatic and edaphic tolerances (Table 3). To estimate $P_{\text {est }}$ for the current climate, 300 weather years were stochastically generated using the means and standard deviations of temperature and precipitation from the Ust-Ilimsk weather record. Each weather year was used to calculate four establishment modifiers for each species: temperature, soil moisture, soil nitrogen, and minimum January temperature. Each modifier varied from 0.0 (complete absence of establishment) to 1.0 (no reduction in the ability to establish). The modifiers were derived from Pastor and Post (1988) and used species vital attributes (drought tolerance, preferred climate, cold tolerance, and soil nitrogen tolerance) and other abiotic characteristics, including soil field capacity, wilting point, and available nitrogen (Table 3). For each weather year the minimum modifier was selected and these minimums were averaged across the 300 weather years to derive the $P_{\text {est }}$ for each species (Table 1).

Fire regimes in the fire extension are specified by an ignition rate and a fire size distribution. We specified size using a duration-based approach, where frequency and size distribution from empirical fire records are used to calibrate a duration distribution for fire events (Didion et al. 2007, Yang et al. 2008). Official statistics underreport fire events by up to an order of magnitude in the study area (Vaschuk 1992, Vaschuk and Shvidenko 2006). Fire parameters (Supplement) were estimated using a combination of official fire occurrence data, remote sensing, and expert knowledge of the fire regime. Fire events are initiated probabilistically (Yang et al. 2004), and the weather associated with each fire is selected from historic weather records by season (e.g., spring leaf-off, summer leaf-on). Fire spread rate is determined by the fuel type of cells as they burn, and is modified according to wind speed and direction and topography using equations from the Canadian Fire Behavior Prediction System (Forestry Canada Fire Danger Group 1992). Site-level fire severity class is translated from the estimated crown fraction burned, based on local spread rates and fuel type (Forestry Canada Fire Danger Group 1992). 
TABLE 2. Extended.

\begin{tabular}{ccc}
\hline $\begin{array}{c}\text { Optimum growing } \\
\text { temperature } \\
\left({ }^{\circ} \mathrm{C}\right)\end{array}$ & $\begin{array}{c}\text { Minimum growing } \\
\text { temperature } \\
\left({ }^{\circ} \mathrm{C}\right)\end{array}$ & $\begin{array}{c}\text { Water-holding } \\
\text { capacity } \\
(\mathrm{cm})\end{array}$ \\
\hline 25 & 0 & 18 \\
22 & 1 & 18 \\
25 & 2 & 17 \\
20 & 0 & 12 \\
25 & 0 & 18 \\
25 & 0 & 17 \\
25 & 1 & 18
\end{tabular}

For the purposes of our study, the model must be able to reliably predict the dynamics of the response variables in the study area under the various disturbance regimes simulated. In the LANDIS-II modeling framework, these dynamics are the cumulative consequence of the multiple succession and disturbance processes simulated. It is virtually impossible to assess the reliability of the model for combinations of processes that currently cannot be observed empirically, but it is feasible to assess the reliability of the model's projections under historical conditions. To this end we constructed a scenario representing the historic range of natural variability (HRNV). We simulated three replicates of current climate, current wind, and fire regimes for 200 years (timber harvest and insect outbreaks were excluded). Model behavior and predicted forest dynamics were evaluated by experts knowledgeable of the forest dynamics of the region using the approach of Gustafson et al. (2006). We also compared projections of forest composition and fire behavior to empirical estimates for the entire Severny lehoz in recent times, to determine if simulated behavior fell within empirical limits. We also conducted a sensitivity analysis by varying the key input parameter values by $\pm 10 \%$ with three replicates and calculated the probability that the perturbed parameters do not have a significant effect on the response variables, as an index of sensitivity. We did not conduct a sensitivity analysis on harvest parameters because we assumed that harvest activities will follow management policies, and these by definition are known with certainty. However, there remains uncertainty about how policies may change over time. Species' vital attributes other than dispersal distance were not tested because the attributes have been well studied and uncertainty is relatively low. Dispersal distance is highly uncertain because a dispersal distance graph is asymptotic, and its truncation is arbitrary. Our primary objective in calibrating dispersal distance was to ensure that species could colonize suitable sites at rates that mimic empirical colonization rates.

\section{Simulation experiment}

We designed a factorial experiment with three independent treatments. The climate treatment had two levels (current climate and future climate). The harvest treatment had two levels (no harvest, legal harvest regime). The insect mortality treatment had two levels (with and without insect outbreaks). The fire regime was not varied as a treatment effect, but responded to the vegetation produced by the interactions among climate, succession, harvest activity, and insect mortality. All other model inputs were held constant. Each treatment combination was simulated for 300 years with three replicates. Three replicates was the minimum number required to achieve a power $>0.99$ based on a power analysis of the variability of the response variables (Murphy and Myors 2003).

The climate treatment modified the climate parameters used by LANDIS-II based on projections of the Hadley GCM (UKMO-HadCM3) A2 scenario (Gordon et al. 2000) for the years 2080-2099. The A2 scenario represents high $\mathrm{CO}_{2}$ emissions due to high population size and slow technological adaptation (IPCC 2007). We chose the Hadley GCM because it is widely respected and it provides the best opportunity to detect climate effects in our experiment because it projects warmer summer temperatures (and similar precipitation) compared with many other GCMs. However, the Hadley predictions of temperature and precipitation differ less than one standard deviation from the average of the projections of seven IPCC GCMs (Ruosteenoja et al. 2003). Climate variability projected by GCMs is similar to that found in the 20-year current climate record. Because calibration is suspect between current climate averages and GCM predictions for the current period, we computed the change in temperature (degrees

TABle 3. Species life history parameters used to calculate the probability of establishment, $P_{\text {est }}$.

\begin{tabular}{lccccc}
\hline \hline \multicolumn{1}{c}{ Species } & $\begin{array}{c}\text { Drought tolerance } \\
\text { (\% growing season) }\end{array}$ & $\begin{array}{c}\text { Minimum } \\
\text { GDD }\end{array}$ & $\begin{array}{c}\text { Maximum } \\
\text { GDD }\end{array}$ & $\begin{array}{c}\text { Minimum January } \\
\text { temperature }\left({ }^{\circ} \mathrm{C}\right)\end{array}$ & $\begin{array}{c}\text { Ability to tolerate } \\
\text { low nitrogen }\end{array}$ \\
\hline Pinus sylvestris & 38 & 730 & 3100 & -55 & high \\
Picea obovata & 25 & 750 & 2500 & -58 & medium \\
Abies sibirica & 16 & 950 & 2500 & -55 & low \\
Larix sibirica & 33 & 670 & 3000 & -66 & high \\
Betula pendula & 31 & 700 & 3200 & -59 & medium \\
Populus tremula & 25 & 900 & 3000 & -45 & medium \\
Pinus sibirica & 23 & 700 & 2300 & -58 & medium \\
\hline
\end{tabular}

Notes: Mean soil parameters for the study area were field capacity $=19 \mathrm{~cm}$, wilting point $=8.75 \mathrm{~cm}$, and base soil $\mathrm{N}=11.0$ $\mathrm{Mg} / \mathrm{ha}$. Parameter values were derived from the Russian ecological literature and expert opinion. GDD stands for growing degreedays (base $=5^{\circ} \mathrm{C}$ ). 
TABLE 4. Harvest parameters.

\begin{tabular}{|c|c|c|c|c|c|}
\hline Species & $\begin{array}{c}\text { Area harvested } \\
\text { (\% of study } \\
\text { area/decade) }\end{array}$ & $\begin{array}{c}\text { Age range } \\
(\mathrm{yr})\end{array}$ & $\begin{array}{l}\text { Cutting } \\
\text { method }\end{array}$ & $\begin{array}{l}\text { Cutblock } \\
\text { size (ha) }\end{array}$ & Regeneration \\
\hline Pinus sylvestris & 1.56 & $101-300$ & clearcut & 40 & Scots pine $(60 \%)$ or larch $(40 \%)$ \\
\hline Picea obovata & 1.06 & $101-300$ & clearcut & 40 & spruce \\
\hline Abies sibirica & 0.47 & $101-211$ & clearcut & 40 & fir \\
\hline Larix sibirica & 1.167 & $101-380$ & clearcut & 40 & larch $(60 \%)$ or Scots pine $(40 \%)$ \\
\hline $\begin{array}{l}\text { Betula pendula/ } \\
\text { Populus tremula }\end{array}$ & 1.60 & $61-131$ & clearcut & 40 & natural \\
\hline Pinus sibirica & 2.5 & $100-450$ & partial biomass removal & whole stand & natural \\
\hline
\end{tabular}

Notes: All prescriptions used MaxCohortAge ranking method and required neighboring stands to be at least five years old (except Pinus sibirica selection cutting). To simulate the commonly used seed tree harvest method, we used the clearcut option in the LANDIS-II harvest extension and the planting option to ensure regeneration of species as indicated. The complete parameter file is found in the Supplement.

Celsius) and precipitation (percent) between the Hadley predictions for the periods 1980-1999 and 2080-2099, and modified the current climate means and daily weather records by those amounts. Mean monthly temperatures in the study area were predicted to rise by about $5^{\circ} \mathrm{C}$ during the 21 st century by the Hadley GCM, and annual precipitation was predicted to increase by $\sim 20 \%$. For the study area, the precipitation and temperature trends predicted by the GCM were linear through the 21 st century, and the variability of temperature and precipitation did not change through time. Future ANPP (Table 1) was estimated by modifying only the PnET climate file, changing mean climate parameters as predicted by the Hadley GCM for the period 2080-2099. To simulate a somewhat gradual change in climate under the future climate treatment scenarios, ANPP values for the future climate treatment initially took current values, but were changed periodically by modifying ANPP for each species at years 40 , 70 , and 100 using linear interpolation of values calculated for years zero and 100 . We assumed that there would be no temperature or moisture acclimation due to $\mathrm{CO}_{2}$ fertilization (Ollinger et al. 2002, Xu et al. 2007). We estimated $P_{\text {est }}$ for the future climate using the same procedure as for current climate, but using climate means modified by the projection of the Hadley GCM. $P_{\text {est }}$ values of the future climate treatment were also modified at years 40,70 , and 100 .

The climate treatment also affected the daily weather record used by the fire extension. We used the daily weather record as modified by the projections of the GCM, again modifying the record at years 40,70 , and 100. To avoid using ad hoc estimates of the future fire size distribution, we specified the fire regime using fire durations. Because future precipitation is not expected to decrease and drought occurrence is not projected to change significantly in the study area (MalevskyMalevich et al. 2008), we assumed that the length of time between fire-extinguishing rain events would not increase, and therefore, the duration of fires would not increase. Accordingly, when simulating the future fire regime we did not modify the duration distribution, instead letting the modified temperature and precipitation regime affect fire spread rates (and therefore fire size) and severity as emergent properties of the fire spread algorithms of the Dynamic Fire System extension. The mean number of fires per year was increased by $10 \%$ to reflect a longer fire season and warmer days under a warmer future climate. All other fire parameters were held constant. We included insect mortality as a treatment effect in the experimental design because insect outbreaks do not currently occur in the study area.

The timber harvest treatment used harvest extension parameters that were estimated based on the current regulations for forest enterprises in the region, and assumes only legal harvest activity (Table 4). All species except stone pine were harvested by clear-cutting, and our harvest rules forced the regeneration of the dominant species. The insect treatment used outbreak parameters that were estimated by expert opinion (L. Vaschuk, V. Pet'ko, and V. Soldatov, personal communication) based on silk moth dynamics in southern Siberia (zone of southern taiga; Supplement). Outbreaks were simulated to occur every 20-30 years. Data on the spatial pattern of silk moth outbreaks were not available, so we assumed that silk moth outbreaks were similar to patterns seen in spruce budworm outbreaks in Canada (Peltonen et al. 2002), where defoliation damage is patchily distributed at a resolution similar to our 100m cell size (Kneeshaw and Bergeron 1998).

Landscape response to the main effects was quantified by measures of forest composition, forest biomass, and the landscape pattern of the forest. Model output primarily consists of maps. For this study we requested maps every 10 years of dominant species (determined by age relative to longevity), maximum cohort age (all species combined), living biomass (all species), fire severity, wind damage severity, and insect outbreak severity. The composition variables were the proportion of the landscape dominated by each species and species evenness (Shannon and Weaver 1949). We also examined age class composition using five generic age-based seral stages: 1-40 years (establishment), 41-100 years 
TABLE 5. MANOVA results for composition variables.

\begin{tabular}{|c|c|c|c|c|c|c|c|c|}
\hline \multirow[b]{2}{*}{ Variable } & \multicolumn{2}{|c|}{ Climate effect $\dagger$} & \multicolumn{2}{|c|}{ Harvest effect $\ddagger$} & \multicolumn{2}{|c|}{ Insect effect§ } & \multicolumn{2}{|c|}{ Harvest $\times$ insect } \\
\hline & $\begin{array}{c}\text { Variation } \\
\text { explained (\%) }\end{array}$ & $t$ & $\begin{array}{c}\text { Variation } \\
\text { explained (\%) }\end{array}$ & $t$ & $\begin{array}{c}\text { Variation } \\
\text { explained (\%) }\end{array}$ & $t$ & $\begin{array}{c}\text { Variation } \\
\text { explained (\%) }\end{array}$ & $R^{2}$ \\
\hline \multicolumn{9}{|l|}{ Simulation year 150} \\
\hline Spruce $(\%)$ & 6.4 & -12.1 & 1.9 & -6.6 & 90.8 & -45.6 & 0.05 & 0.99 \\
\hline Scots pine $(\%)$ & 11.8 & 11.9 & 35.5 & 20.6 & 41.4 & -22.3 & $9.7 * *$ & 0.98 \\
\hline $\operatorname{Larch}(\%)$ & 0.1 & -1.8 & 84.0 & -53.8 & 12.6 & 20.9 & $2.7 * *$ & 0.99 \\
\hline Mid-seral (\%) & 6.4 & -2.0 & 12.6 & 2.80 & 49.4 & 5.6 & 1.1 & 0.70 \\
\hline Old growth (\%) & 0.1 & -3.1 & 82.9 & -87.4 & 12.5 & -34.0 & $4.2^{* *}$ & 1.00 \\
\hline \multicolumn{9}{|l|}{ Simulation year 300} \\
\hline Spruce $(\%)$ & 7.5 & -10.7 & 28.2 & -20.7 & 52.3 & -28.2 & $10.6^{* *}$ & 0.99 \\
\hline Scots pine $(\%)$ & 65.1 & 18.3 & 30.2 & 12.4 & 1.0 & 2.3 & 0.03 & 0.96 \\
\hline Larch $(\%)$ & 0.02 & -0.58 & 37.8 & -24.2 & 49.7 & 27.8 & $11.2 * *$ & 0.99 \\
\hline Mid-seral (\%) & 4.5 & 3.1 & 18.0 & 6.2 & 59.1 & 11.2 & $9.4^{* *}$ & 0.91 \\
\hline Old growth (\%) & 0.8 & -3.9 & 82.4 & -38.8 & 8.8 & -12.7 & $6.9 * *$ & 0.99 \\
\hline
\end{tabular}

Notes: The $t$ values test the hypothesis that the response between levels of the main effect are equal, and significant $(\alpha=0.01)$ differences are indicated in boldface. Global treatment effects were significant for all three main effects in both analysis years. Only the harvest $\times$ insect interaction was always significant in both years and was the only interaction included in the model. Significant interactions are indicated by asterisks.

$* * P<0.01$.

$\dagger$ Positive $t$ value means that response variable increases as climate changes from current to future.

$\$$ Positive $t$ value means that response variable increases when harvest regime is added.

$\S$ Positive $t$ value means that response variable increases when insect disturbance is added.

(early-seral), 101-140 years (mid-seral), 141-180 years (late-seral), and $>180$ years (old-growth), as well as seral stage evenness. The biomass variable was the total aboveground live biomass (AGB) across the landscape. Pattern variables were the mean distance of forested cells to an edge (GISfrag of Ripple et al. 1991) where edges were caused by non-forested cells or forested cells with a maximum cohort age $\leq 20$ years, maximum patch size, and the aggregation index (He et al. 2000) by species and seral stage. The biomass variable was output directly by LANDIS-II; all other variables were calculated with IAN (DeZonia and Mladenoff 2004) or HARVEST (Gustafson and Rasmussen 2002).

Treatment effects were calculated using multiple analysis of variance (MANOVA) models, which allow for global hypothesis tests of factor effects for multiple dependent variables (Johnson and Wichern 1992). Separate analyses were conducted for each of the three categories of response variables (composition, biomass, and spatial pattern). Within each analysis, a subset of representative variables was chosen to reduce multicollinearity (see Table 5). Because the response variables varied through time, we chose simulation years 150 and 300 as representative of the varying response. The MANOVA models used the error sums of squares and cross products (residual) matrix, and the results were evaluated using Type I sums of squares. The relative influence of each main effect was quantified as the percent of the total variation attributed to each effect. Significance was judged conservatively using $\alpha=0.01$ because random noise was minimal in this tightly controlled simulation experiment. Therefore, our interpretations focus on trends rather than significance per se.

\section{RESUlTS}

Simulation of the historical climate and disturbance regimes (HRNV) showed variation within the empirical range of proportions for most species and age classes (Table 6). Because LANDIS-II is primarily a processbased model, we concluded that the process algorithms and parameters adequately represented the dynamics of this Siberian ecosystem, and that treatments imposed by modifying climate-related parameters and adding disturbances would provide useful insights.

Response variables were relatively insensitive to wind disturbance parameters (disturbance size, frequency, and age-related mortality function; Table 7). Biomass estimates were very sensitive to ANPP, but age and species response variables generally were not. All response variables were very sensitive to establishment probabilities, seed dispersal distance estimates, and the amount of AGB necessary to achieve the five shade classes at a site (Scheller and Mladenoff 2004). Response variables were generally sensitive to the parameter defining the mean of the lognormal fire size distribution $(\mu)$, but not to the shape parameter $(\sigma)$ or the number of fires.

\section{Effect of treatments on forest composition}

The experimental results show that forest composition response variables were influenced most strongly by the timber harvest and insect treatments (Table 5). The climate treatment had a significant effect, but its effect was minor compared to the other main effects, excepting the abundance of Scots pine. Scots pine (and aspen) has increased ANPP and $P_{\text {est }}$ under future climate, while the other species have small or opposite 
TABLE 6. Comparison of the Historic Range of Natural Variability scenario (200 years) to empirical estimates of species and age composition to assess model performance.

\begin{tabular}{lcccc}
\hline \hline Forest composition class & $\begin{array}{c}\text { Empirical } \\
\text { (expected) }(\%)\end{array}$ & $\begin{array}{c}\text { Initial conditions, } \\
\text { year 0 }(\%)\end{array}$ & $\begin{array}{c}\text { Range, years } \\
10-200(\%)\end{array}$ & $\begin{array}{c}\text { Mean, years } \\
10-200(\%)\end{array}$ \\
\hline Picea obovata & $6-25$ & 19 & $12-18$ & 16.0 \\
Abies sibirica & $5-10$ & 8 & $1-8$ & 2.4 \\
Larix sibirica & $15-35$ & 21 & $24-45$ & 35.4 \\
Pinus sylvestris & $20-40$ & 26 & $22-28$ & 25.0 \\
Pinus sibirica & $7-14$ & 10 & $10-14$ & 11.9 \\
Betula pendula & $4-10$ & 4 & $4-5$ & 4.2 \\
Populus tremula & $4-15$ & 12 & $1-12$ & 3.9 \\
Establishment $(1-40 \mathrm{yr})$ & $5-15$ & 12 & $2-8$ & 5.0 \\
Early-seral (41-100 yr) & $5-25$ & 23 & $5-23$ & 10.7 \\
Mid-seral $(101-140 \mathrm{yr})$ & $5-20$ & 19 & $6-17$ & 10.6 \\
Late-seral $(141-180 \mathrm{yr})$ & $10-30$ & 24 & $5-24$ & 13.2 \\
Old growth $(>180 \mathrm{yr})$ & $40-65$ & 22 & $29-73$ & 59.3 \\
\hline
\end{tabular}

Notes: Empirical proportions were based on official statistics and expert estimates of species composition in unharvested sites similar to the study area within the Severny lehoz. The range and mean columns show the simulated composition of three replicates.

changes in those two parameters (Table 1). The negative effect of climate on the abundance of old growth is likely related to the increase in the $P_{\text {est }}$ of the short-lived aspen, and an increase in fire under future climate. Harvest had a negative effect on larch and spruce and a positive effect on Scots pine. Because larch is less shade tolerant than Scots pine, larch was less likely to regain dominance in clear-cut stands than Scots pine. In most cases pioneer species also colonized clear-cut sites. Spruce grows slower than the pioneer species and therefore tended not to regain dominance for a considerable time. The effect of insects on spruce in year 150 is markedly greater than in year 300. The initial insect outbreaks were the most severe, and disproportionately impacted spruce because of its relative abundance at year 0 (Table 6) and its susceptibility to the silk moth (Supplement). Insects did not negatively influence larch because larch is rarely killed in outbreaks, nor birch or aspen, which are not silk moth hosts. Because insects are more likely to kill older cohorts, the abundance of mid-seral forest increased and the abundance of old growth decreased. The only interaction consistently significant was between harvest and insects. Harvest tends to increase Scots pine and reduce larch, but this trend is reversed when insect outbreaks occur because insects are more likely to kill pines than larch. Also, the effect of insects on forest composition was muted in the presence of harvesting,

TABLE 7. Sensitivity analysis was conducted by perturbing the input parameter values for the Historic Range of Natural Variability scenario by $\pm 10 \%$.

\begin{tabular}{|c|c|c|c|c|c|c|c|c|c|}
\hline \multirow[b]{2}{*}{ Response variable } & \multicolumn{9}{|c|}{ Input parameter } \\
\hline & $\begin{array}{l}\text { Shade } \\
\text { class } †\end{array}$ & ANPP & $P_{\text {est }}$ & $\begin{array}{c}\text { Maximum } \\
\text { dispersal } \\
\text { distance }(\mathrm{m})\end{array}$ & $\begin{array}{c}\text { Mean wind } \\
\text { event size } \\
\text { (ha) }\end{array}$ & $\begin{array}{l}\text { Wind } \\
\text { rotation } \\
(\mathrm{yr}) \S\end{array}$ & $\begin{array}{c}\text { Wind } \\
\text { severity }\end{array}$ & $\begin{array}{c}\text { No. fires } \\
\text { (no./ } \\
\text { study area) }\end{array}$ & $\begin{array}{c}\text { Fire size } \\
\text { distribution } \\
(\mu)\end{array}$ \\
\hline Spruce $(\%)$ & $<0.0001$ & 0.633 & $<0.0001$ & $<0.0001$ & 0.009 & 0.680 & 0.906 & 0.268 & 0.0009 \\
\hline Scots pine $(\%)$ & 0.0002 & 0.132 & $<0.0001$ & $<0.0001$ & 0.293 & 0.822 & 0.405 & 0.015 & $<0.0001$ \\
\hline Larch (\%) & 0.0003 & 0.358 & $<0.0001$ & $<0.0001$ & 0.030 & 0.465 & 0.903 & 0.340 & 0.010 \\
\hline Mid-seral (\%) & $<0.0001$ & 0.441 & $<0.0001$ & $<0.0001$ & 0.018 & 0.801 & 0.917 & 0.430 & 0.0002 \\
\hline Old growth (\%) & $<0.0001$ & 0.022 & $<0.0001$ & $<0.0001$ & 0.012 & 0.788 & 0.890 & 0.534 & 0.0003 \\
\hline Total biomass & $<0.0001$ & $<0.0001$ & $<0.0001$ & $<0.0001$ & 0.013 & 0.226 & 0.845 & 0.803 & 0.092 \\
\hline GISfrag\# & 0.371 & 0.584 & 0.374 & 0.866 & 0.037 & 0.656 & 0.365 & 0.546 & 0.022 \\
\hline AI-species $† \dagger$ & 0.001 & 0.422 & $<0.0001$ & 0.007 & 0.679 & 0.299 & 0.682 & 0.392 & 0.002 \\
\hline AI-seral stage & $<0.0001$ & 0.216 & $<0.0001$ & $<0.0001$ & 0.007 & 0.722 & 0.740 & 0.356 & 0.002 \\
\hline Largest patch-species & 0.328 & 0.285 & 0.014 & 0.852 & 0.102 & 0.341 & 0.207 & 0.323 & 0.016 \\
\hline Largest patch-seral stage & $<0.0001$ & 0.094 & $<0.0001$ & $<0.0001$ & 0.011 & 0.789 & 0.881 & 0.150 & 0.022 \\
\hline
\end{tabular}

Notes: Table values give the probability that the perturbed parameter does not have a significant effect at year $=300$. The full parameter and variable table can be found in the Supplement. Abbreviations are: ANPP, aboveground net primary productivity; $P_{\text {est }}$, probability of establishment.

$\uparrow$ Threshold values (percentage of maximum biomass) for a site to enter a shade class. Shade class ranges from zero (no shade) to 5 (highest shade).

\$ Mean size of areas in which trees are blown down by wind.

$\S$ Mean time for an area equal to the size of the study area to be affected by wind events.

- Age thresholds that determine which cohorts are killed by an event of a given wind severity.

\# GISfrag is a fragmentation index calculated as the mean distance of forested cells from an edge (Ripple et al. 1991).

$\dagger \dagger \mathrm{AI}$ is the aggregation index of He et al. (2000) that reflects the tendency of like cells to be adjacent. 
TABLE 8. ANOVA results for the aboveground biomass (AGB) variable.

\begin{tabular}{|c|c|c|c|c|c|c|c|c|}
\hline \multirow[b]{2}{*}{ Variable } & \multicolumn{2}{|c|}{ Climate effect $\uparrow$} & \multicolumn{2}{|c|}{ Harvest effect $\$$} & \multicolumn{2}{|c|}{ Insect effect§ } & \multicolumn{2}{|c|}{ Harvest $\times$ insect } \\
\hline & $\begin{array}{c}\text { Variation } \\
\text { explained (\%) }\end{array}$ & $t$ & $\begin{array}{c}\text { Variation } \\
\text { explained (\%) }\end{array}$ & $t$ & $\begin{array}{c}\text { Variation } \\
\text { explained (\%) }\end{array}$ & $t$ & $\begin{array}{c}\text { Variation } \\
\text { explained (\%) }\end{array}$ & $R^{2}$ \\
\hline \multicolumn{9}{|c|}{ Simulation year 150} \\
\hline Total AGB & 1.0 & -2.1 & 69.6 & -8.2 & 19.8 & -9.7 & $5.7 * *$ & 0.96 \\
\hline \multicolumn{9}{|c|}{ Simulation year 150} \\
\hline Total AGB & 2.2 & -1.4 & 67.5 & -7.9 & 10.0 & 3.0 & 0.0 & 0.80 \\
\hline
\end{tabular}

presumably because harvests reduce landscape abundance of older cohorts of host species.

\section{Effect of treatments on biomass}

The total AGB response variable responded most strongly to the harvest treatment (Table 8). The climate effect was not only insignificant, but it tended negative. This was likely an indirect effect of climate on the fire regime. The effect of insects on biomass was not consistent through time. The effect was negative at year 150 because the initial outbreaks were more severe than later ones. The effect was positive at year 300 because repeated insect outbreaks favored species with high ANPP, such as birch and larch (Table 1). Similar to forest composition, the effect of insects on biomass was reduced when harvest disturbance was also applied.

\section{Effect of treatments on spatial pattern}

The spatial pattern of response variables were most strongly influenced by the timber harvest and insect treatments, and were almost completely insensitive to climate (Table 9). Both the harvest and insect treatments increased forest fragmentation, although the fragmenting effect of insects was muted in the presence of harvesting, because harvesting has the greater fragmenting effect. The sign and relative strength of the effects was not always consistent through time (e.g., AI-species and AI-seral stage for the harvest effect; Table 9). The likelihood that a disturbance process had a significant effect on spatial pattern appears to be a function of the grain-size of the disturbance events relative to the grain of the existing landscape pattern. When the grain of a disturbance is the same as the existing pattern, pattern

TABLE 9. MANOVA results for spatial pattern variables.

\begin{tabular}{|c|c|c|c|c|c|c|c|c|}
\hline \multirow[b]{2}{*}{ Variable } & \multicolumn{2}{|c|}{ Climate effect $\dagger$} & \multicolumn{2}{|c|}{ Harvest effect $t$} & \multicolumn{2}{|c|}{ Insect effect§ } & \multicolumn{2}{|c|}{ Harvest $\times$ insect } \\
\hline & $\begin{array}{c}\text { Variation } \\
\text { explained (\%) }\end{array}$ & $t$ & $\begin{array}{c}\text { Variation } \\
\text { explained (\%) }\end{array}$ & $t$ & $\begin{array}{c}\text { Variation } \\
\text { explained (\%) }\end{array}$ & $t$ & $\begin{array}{c}\text { Variation } \\
\text { explained (\%) }\end{array}$ & $R^{2}$ \\
\hline \multicolumn{9}{|l|}{ Year 150} \\
\hline $\begin{array}{l}\text { GISfrag- } \\
\text { AI-species\# } \\
\text { AI-seral stage\# } \\
\text { Largest patch-species } \\
\text { Largest patch-seral stage }\end{array}$ & $\begin{array}{l}1.3 \\
0.1 \\
0.2 \\
0.1 \\
0.2\end{array}$ & $\begin{array}{r}-\mathbf{5 . 7} \\
-1.6 \\
-1.7 \\
0.7 \\
0.7\end{array}$ & $\begin{array}{r}44.6 \\
38.3 \\
1.1 \\
66.0 \\
29.2\end{array}$ & $\begin{array}{r}-33.3 \\
-27.9 \\
-4.6 \\
-16.8 \\
-8.7\end{array}$ & $\begin{array}{l}32.9 \\
54.4 \\
79.6 \\
14.2 \\
15.4\end{array}$ & $\begin{array}{r}-28.6 \\
-33.2 \\
-39.4 \\
7.4 \\
-6.3\end{array}$ & $\begin{array}{r}20.4^{* *} \\
6.2^{* *} \\
18.1^{* *} \\
14.8^{* *} \\
47.8^{* *}\end{array}$ & $\begin{array}{l}0.99 \\
0.99 \\
0.99 \\
0.95 \\
0.93\end{array}$ \\
\hline \multicolumn{9}{|l|}{ Year 300} \\
\hline $\begin{array}{l}\text { GISfrag } \\
\text { AI-species\# } \\
\text { AI-seral stage\# } \\
\text { Largest patch-species } \\
\text { Largest patch-seral stage }\end{array}$ & $\begin{array}{l}5.0 \\
0.7 \\
2.8 \\
1.0 \\
0.0\end{array}$ & $\begin{array}{l}-\mathbf{3 . 7} \\
-1.2 \\
-\mathbf{6 . 2} \\
1.0 \\
0.06\end{array}$ & $\begin{array}{r}33.8 \\
1.9 \\
50.0 \\
27.8 \\
0.8\end{array}$ & $\begin{array}{r}-\mathbf{9 . 6} \\
1.9 \\
\mathbf{2 5 . 9} \\
-\mathbf{5 . 4} \\
-0.56\end{array}$ & $\begin{array}{l}27.4 \\
65.5 \\
32.8 \\
24.5 \\
36.5\end{array}$ & $\begin{array}{r}-8.6 \\
-10.8 \\
-21.0 \\
5.1 \\
-3.8\end{array}$ & $\begin{array}{l}26.8^{* *} \\
21.2^{* *} \\
13.0^{* *} \\
28.8^{* *} \\
13.3\end{array}$ & $\begin{array}{l}0.93 \\
0.89 \\
0.98 \\
0.82 \\
0.51\end{array}$ \\
\hline
\end{tabular}

Notes: The $t$ values test the hypothesis that the response between levels of the main effect are equal, and significant $(\alpha=0.01)$ differences are indicated in bold. Global treatment effects were significant for all three main effects in both analysis years. Only the harvest $\times$ insect interaction was always significant in both years, and was the only interaction included in the model. Significant interactions are indicated by asterisks.

$* * P<0.01$.

$\dagger$ Positive $t$ value means that response variable increases as climate changes from current to future.

$\$$ Positive $t$ value means that response variable increases when harvest regime is added.

$\S$ Positive $t$ value means that response variable increases when insect disturbance is added.

- GISfrag is a fragmentation index calculated as the mean distance of forested cells from an edge (Ripple et al. 1991).

\# AI is the aggregation index of He et al. (2000) that reflects the tendency of like cells to be adjacent. 


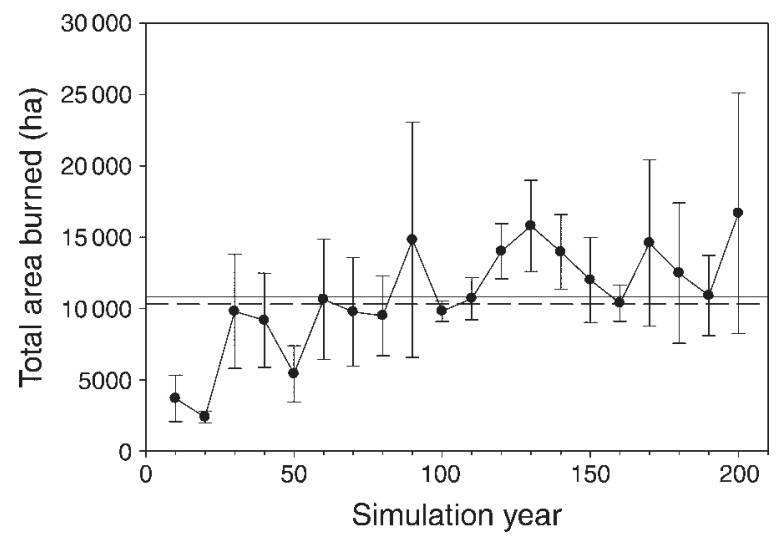

FIG. 2. Total area burned per decade $( \pm S D)$ in the Historic Range of Natural Variability scenario. The solid reference line shows the mean simulated area burned, and the dashed line shows the empirical average for the lehoz (10317.9 ha).

metrics are less likely to detect change. For example, the mean harvest cutblock size ( $40 \mathrm{ha}$ ) is similar to the mean size of seral stage patches in the early years of the simulation, so the effect of the harvest treatment on AI-seral stage at year 150 was not significant (Table 9). But the grain size of the landscape pattern became smaller through time by the action of the various disturbance and succession processes, so that by year 300 , the cutblocks were much bigger than the mean seral stage patch, and the effect on AI-seral stage became significantly positive. The grain of insect disturbance patches was generally smaller than for harvests, so insect effects were more pronounced earlier in the simulations.

\section{DisCUSSION \\ Ecological insights}

When simulating the historical climate and disturbance regime (HRNV), the projections of the model were within the empirical range of proportions for most species and age classes. The most notable discrepancy is with the oldest age class. Official Russian statistics (initial conditions) for uneven-aged stands uses average age, but our analysis of subsequent years uses the oldest age, which inflates the apparent age of older stands. Note that current proportions of some classes are near the extreme of the range of variability. There are several potential explanations for this. (1) The initial landscape has been impacted by some harvesting in the south during the past decade. This represents disturbance that is not "natural." (2) The official data used to define the initial conditions may underreport recent burns. (3) While the model reproduces the empirical (current) fire regime quite closely, the resolution of some disturbance parameters may be too coarse to accurately reproduce the response of some species to disturbance. For example, the difference in fire tolerance between spruce and fir may be less than the model can distinguish. The fire regime is characterized primarily by area burned, the size of fires and the severity of fires. We were able to reproduce the empirical (current) fire regime quite closely (Figs. 2 and 3).

Of the multiple global changes studied, climate had the smallest direct effect on species and seral stage composition, and did not induce changes outside the range of natural variability. However, increased outbreaks by the Siberian silk moth would be an indirect effect of climate warming, and the resulting composition changes (species and ages) may go outside the range of natural variability. Direct climate effects on composition (through alteration of growth rates and probability of establishment) have a lag time, but they induce longlasting ecological changes that interact with other disturbance processes to fundamentally alter the ecosystem dynamics of these forests. In contrast, timber harvest activity produces a sudden and significant change in composition, particularly age class distribution. Of the global changes studied, timber harvest is the one that can be most controlled by managers. Our modeling approach can be used to investigate the ability of alternative silvicultural strategies to mitigate some of the negative effects of climate change.

Estimates of the direct effect of climate change are still contradictory. Some estimates show the productivity of all Russian forests increasing by $\sim 20 \%$ due to global change (climate change, $\mathrm{CO}_{2}$ fertilization, and nitrogen deposition; Alexeyev and Markov 2003), but others predict the productivity increase to be much less in Asian than in European Russia (Shvidenko et al. 2008). Note however, that we did not incorporate $\mathrm{CO}_{2}$ fertilization effects on ANPP (Norby et al. 2005), which may significantly interact with other global change effects (Peng and Apps 1999, Alo and Wang 2008).

Climate did not have a significant effect on total biomass, likely because the positive effects of climate were negated by increased losses to fire. This is generally consistent with projections for boreal forests in Canada

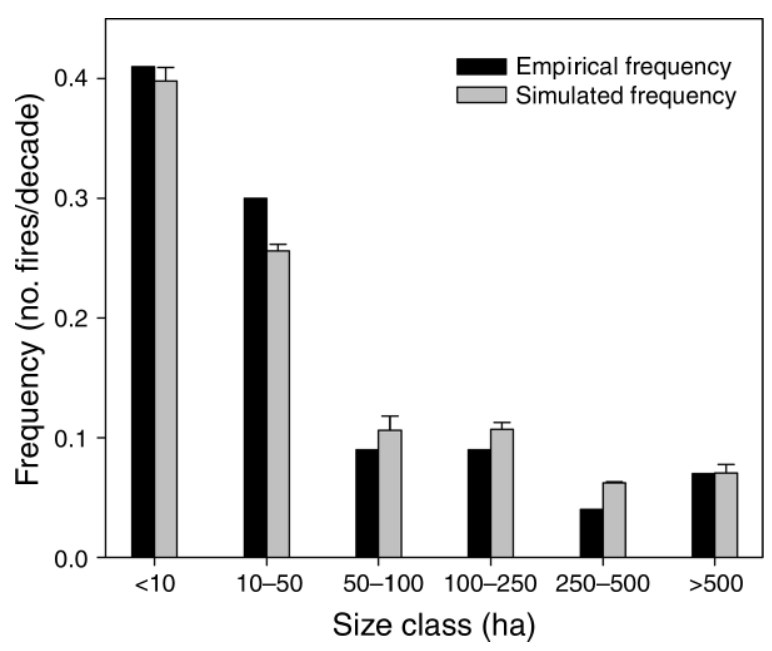

FIG. 3. Size distribution of fires $(+\mathrm{SD})$ in the Historic Range of Natural Variability scenario (200 simulation years). 
(Li et al. 2000, Kang et al. 2006, Girardin and Mudelsee 2008, Kurz et al. 2008). Li et al. (2000) used a similar fire spread model to ours and found that forest volume decreased due to increased fire incidence on the landscape. Conversely, Flannigan et al. (2001) found large variability across Canada with a decline of fire in eastern Canada. Considering the maritime influences on the climate in eastern Canada, our study area is more analogous to the continental climate of central Canada.

As expected, timber harvest greatly reduced biomass on the landscape. Insects initially reduced biomass, but over time the extent and severity of the outbreaks became less as the species composition changed to less vulnerable and more productive species. Together, these findings suggest that the ability of forests in the region to continue to retain aboveground carbon over the next century will be compromised significantly by the global changes that are occurring unless the end products of harvested wood are long lived (up to 300 years).

Climate had little direct effect on landscape pattern because it was a ubiquitous, nonspatial main effect, and apparently had no strong indirect spatial effects. Conversely, the spatially explicit disturbance processes had strong spatial effects. Based on simulation results, Pastor et al. (1999) reported that the spatial patterning of boreal landscapes is strongly influenced by tree seed dispersal and competition, mobile herbivores that discriminate among forage species (such as moose), insect outbreaks, and fire. In our study, the strength of such effects was related to the scale of the process relative to the existing landscape pattern, and this changed through time. In contrast to the decreased fragmentation due to climate change and fire estimated by $\mathrm{Li}$ et al. (2000), our results consistently show that fragmentation may be increased by harvest and insects, and the relative strength of the effect is consistent across years (Table 9). The increase in fragmentation caused by harvest and insects would be expected to have negative consequences for forest interior species and enhance populations of edge species (Stephens et al. 2004, but see Schmiegelow and Mönkkönen 2002). More specific conclusions would require a more detailed analysis of changes in habitat conditions, including tree species, seral stages, patch sizes, and connectivity relative to specific species' life history requirements. Although our results do not suggest any catastrophic threats by global change to the productivity of forests of the region, it is less clear how their ecological sustainability may be affected. Changes resulting from harvesting and insect outbreaks may in some cases take ecosystems outside the historic range of variability in species and age composition. The ecological consequences of such changes deserve further study.

It is important to note that there are potential artifacts related to the resolution and grid cell structure used to represent the landscape. The grain size of the initial conditions map reflected the arbitrary mapping units (stands) used to represent the landscape. The LANDIS-
II model operates on the cell as the basic spatial unit, and over simulated time the stands were disaggregated and spatial autocorrelation was reduced. Therefore, some of the spatial pattern changes over time are an artifact of the coarse resolution of some model inputs, although these artifacts reach equilibrium by year 150 . The resolution of simulated disturbances may also be in error. Fire events are highly variable in size, but we corroborated the size distribution of fires (Fig. 3). Harvest cutblock sizes were specified according to Russian law. The spatial pattern (grain and extent) of silk moth outbreaks were assumed to be similar to those of spruce budworm outbreaks in Canada (Kneeshaw and Bergeron 1998, Peltonen et al. 2002).

Because Siberian forests are one of the few remaining unexploited ecosystems, they provide an excellent opportunity to compare the relative effects of direct human effects (harvesting) as compared to climate change effects (both direct effects and the indirect effect of increased insect activity and fire). In much of the rest of the world, human effects on forested landscapes are continuous and complex, making it difficult to separate human effects from natural disturbance processes. The implication of our research is that projections of forest change (Purves and Pacala 2008) that do not explicitly consider harvesting (Ravenscroft et al. 2010) and other land use changes (Foley et al. 2005) may underestimate the potential magnitude of change. These direct effects will further exacerbate and may exceed the current uncertainties of global models of forest interactions with climate (Cramer et al. 2001, Purves and Pacala 2008).

\section{Modeling limitations}

Definitive validation of our modeling system by comparison to empirical observations will not be possible for at least 100 years. Confidence in our results is based on (1) the extensive testing and application of LANDIS-II model core assumptions and extensions in previous studies (Sturtevant et al. 2004a), (2) finding that the behavior of all components under a current climate and disturbance (HRNV) scenario matches expert opinion about forest succession and disturbance dynamics in this part of Siberia, (3) finding that the proportions of species and age classes falls within observed ranges for the region under an HRNV scenario, (4) sensitivity analysis that showed that model behavior responds to input parameters as expected by the conceptual model(s) on which LANDIS-II is based, (5) none of the direct results (in the absence of interactions) was counterintuitive, and (6) we limited our conclusions to the results of the experimental manipulations without affirming the specific predictions about future ecosystem states of the study area. Our study seeks first principles of ecosystem response under the specific assumptions of LANDIS-II and the input parameters we used. Therefore, given that LANDIS-II represents current ecosystem process knowledge and the input parameters were derived from empirical data, the direction and 


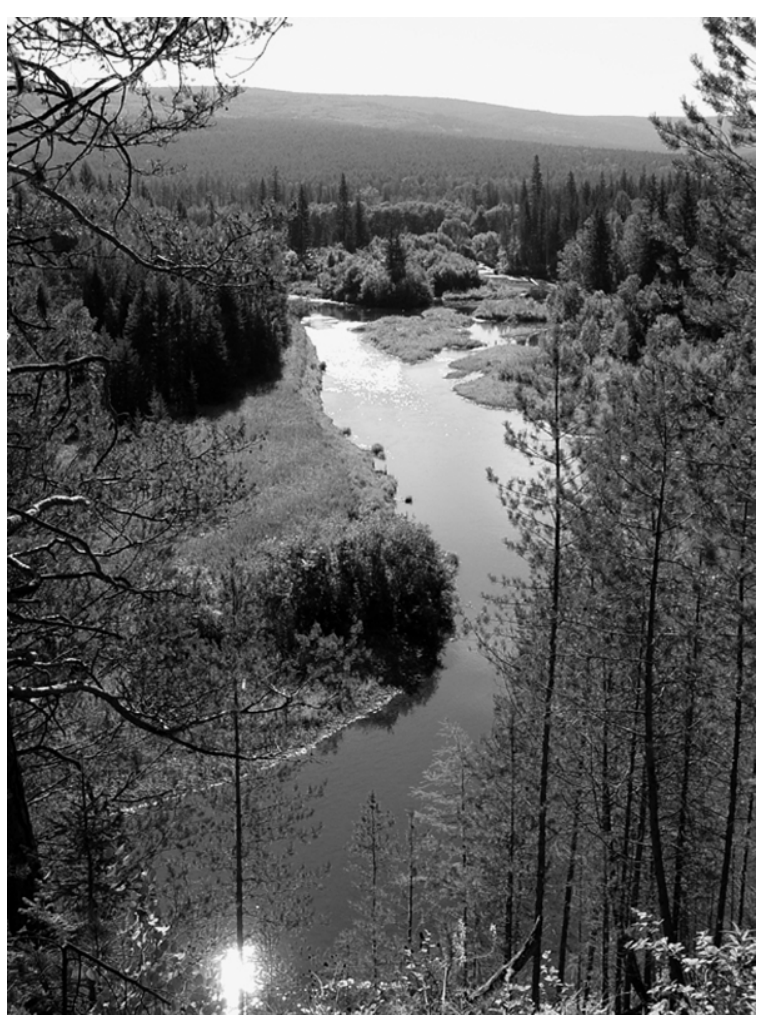

Plate 1. Siberian southern taiga forest in the basin of the Angara river, typical of forests found in the study area. Photo credit: Leonid Vaschuk.

relative magnitude of the response to the treatment effects can provide insights with some confidence. There was unavoidable uncertainty associated with the input parameters, but this uncertainty was not high for the parameters to which our results were most sensitive (Table 7).

Our results were affected by a number of factors with inherent uncertainty (Xu et al. 2007). The initial conditions map was derived for the Siberia-II project (Schmullius et al. 2003) based on Russian forest inventory data. While these data are reliable for species composition, they may be less reliable for age structure because the inventory data record only the oldest cohort. For example, the initial conditions map showed little evidence of recent stand-replacing fires. Based on other evidence it is likely that official fire records underreport fire events by an order of magnitude (Vaschuk and Shvidenko 2006). We corrected for this bias in our fire regime parameters, but made no changes to the initial conditions map. The model parameters determine succession and disturbance behavior, which generates patterns of forest dynamics. These dynamics appear to replace the pattern found in the initial conditions map within about 100 years.

The many parameters used to specify succession and disturbance processes are themselves subject to uncertainty. ANPP and establishment probabilities were estimated using models developed in North America (PnET-II, $P_{\text {est }}$ estimator) that have never been applied to Russian species. While the ANPP predictions for the current climate were readily calibrated to empirical observations, there is inherent uncertainty in the projections under future climate. However, our confidence in these parameters is high because the relationships in the models are based on first principles that have been shown to be robust across species and regions. Similarly, uncertainty is low for many of the species' life attributes and the disturbance parameters because they are based on much empirical study of similar ecosystems by Russian scientists. On the other hand, GCM models are highly uncertain, although the predicted response to a given climate prediction is less uncertain. We did not evaluate the sensitivity of our results to various emission scenarios and climate projections, focusing instead on the effect of a somewhat extreme climate scenario relative to other global changes (harvest and insects). Using a different climate projection would have changed our results to some degree, but it is unlikely that the conclusions drawn from the experiment would change.

The sensitivity of our simulations to parameter perturbations, coupled with the accumulation of uncertainty across multiple parameters, suggests that caution should be exercised when interpreting our results. However, we believe that our results can infer the direction of trends reliably (rather than the magnitude of changes), and can provide insight into the nature of the interactions among the multiple global changes that are otherwise extremely difficult to study.

Simulating the response of fire to future climate required several key assumptions. LANDIS-II simulates fire regimes by probabilistically simulating fire ignitions (by all causes) and then the spread of "successful" ignitions. The number of ignition attempts per year is given as an input parameter, and the success of those attempts depends on the vegetation (fuel type) at the ignition site. We assumed that the primary effect of warmer and wetter climate on ignition rates was to lengthen the fire season by $10 \%$ and to increase fire spread rates (on average), but to have no effect on ignition rates per se. The fire duration distribution was the same for both current and future scenarios, and actual fire sizes depended on fuel and weather. The advantage of this approach is that fire behavior was less arbitrarily specified and was more of an emergent property of the interacting ecological processes, climate, and the experimental treatments. However, a key uncertainty in our fire modeling is the ability of the Canadian Fire Prediction System fuel models to accurately predict fire spread rates in Siberian forests. The fuel models have not been empirically validated in Siberia, although such work is underway (McRae et al. 2006). Local fire experts affirm the applicability of this system to Siberian conditions (Sofronov et al. 2005). Nevertheless, these uncertainties make us cautious about concluding that our model makes robust predictions 
about the future fire regime, though our results should be as reliable as those of similar studies.

As with all simulation models, LANDIS-II is a computational formalization of conceptual models of ecological processes and assumptions about how they interact with specific forest conditions and with each other. For many processes these models and assumptions are firmly established, but for others little is known about the true behavior of the process. LANDIS-II integrates a large body of established scientific knowledge of how ecological processes operate locally and spatially on forested sites. Therefore, our results should be viewed as the logical consequence of these assumptions and the input data. LANDIS-II may have some ability to predict expected future states of Siberian landscapes, but the cumulative uncertainty is not trivial. Our approach was to focus on trends, interactions, and the relative importance of multiple global change factors. Using LANDIS-II to conduct a controlled experiment allows discovery of general trends of boreal ecosystem response to multiple global changes, given our current understanding of the ecological processes that structure forests and landscapes.

\section{Conclusions}

From our study we draw the following conclusions. (1) Global change is likely to significantly change forest composition of south-central Siberian landscapes, with some changes taking ecosystems outside the historic range of variability. (2) The direct effects of climate change in the study area are not as significant as the exploitation of virgin forest by timber harvest and the potential increased outbreaks of the Siberian silk moth. (3) Disturbance by timber harvest and insect outbreaks may greatly reduce the AGB of Siberian forests, and may significantly alter ecosystem dynamics and wildlife populations by increasing forest fragmentation.

\section{ACKNOWLEDGMENTS}

We thank Leonid Vaschuk for sharing his expert knowledge of the forests of the Irkutsk Oblast to improve our ability to simulate their dynamics. Vladimir Pet'ko helped generate estimates of silk moth parameters. Rachel Pinker provided estimates of photosynthetically active radiation for the UstIlimsk study site. Doug McRae provided Siberian weather data. We acknowledge the modeling groups, the Program for Climate Model Diagnosis and Intercomparison (PCMDI) and the WCRP's Working Group on Coupled Modelling (WGCM), for their roles in making available the WCRP CMIP3 multimodel data set. Support of this data set is provided by the Office of Science, U.S. Department of Energy. Weimin Xi developed LandisView for viewing LANDIS-II map output. John Brissette and Patrick James provided extremely valuable critical reviews of the manuscript. Funding was provided by the Northern Research Station and the International Institute for Applied Systems Analysis.

\section{Literature Cited}

Aber, J. D., S. V. Ollinger, C. A. Federer, P. B. Reich, M. L. Goulden, D. W. Kicklighter, J. M. Mellilo, and R. G. Lathrop. 1995. Predicting the effects of climate change on water yield and forest production in the northeastern US. Climate Change Research 5:207-222.

Alexeyev, V. A., and M. V. Markov. 2003. Statistical data on forest fund and change of productivity of forests of Russia in the second half of XX century. [In Russian.] Saint-Petersburg Forestry Research Institute, Saint Petersburg, Russia.

Alo, C. A., and G. L. Wang. 2008. Hydrological impact of the potential future vegetation response to climate changes projected by 8 GCMs. Journal of Geophysical ResearchBiogeosciences 113:G03011.

Bale, J. S., et al. 2002. Herbivory in global climate change research: direct effects of rising temperature on insect herbivores. Global Change Biology 8:1-16.

Cramer, W., et al. 2001. Global response of terrestrial ecosystem structure and function to $\mathrm{CO}_{2}$ and climate change: results from six dynamic global vegetation models. Global Change Biology 7:357-373.

Dale, V. H., et al. 2001. Climate change and forest disturbances. Bioscience 51:723-734.

DeZonia, B., and D. J. Mladenoff. 2004. IAN 1.0.15. University of Wisconsin, Madison, Wisconsin, USA. $\langle\mathrm{http}: / /$ landscape.forest.wisc.edu/projects/ian/〉

Didion, M., M. J. Fortin, and A. Fall. 2007. Forest age structure as indicator of boreal forest sustainability under alternative management and fire regimes: a landscape level sensitivity analysis. Ecological Modelling 200:45-58.

Dirk, B., D. Nielson, and L. Tangley. 1997. The last frontier forests. World Resources Institute, Washington, USA.

Efremov, D. F., and A. Z. Shvidenko. 2004. Long period ecological consequences of catastrophic fires in forests of the Russian Far East and their impact on global processes. Pages 66-73 in Proceedings of International Scientific and Practical Seminar, Khabarovsk, Russia, 9-12 September 2003. [In Russian.] World Bank, Moscow.

Euskirchen, E. S., A. D. McGuire, D. W. Kicklighter, Q. Zhuang, J. S. Clein, R. J. Dargaville, D. G. Dye, J. S. Kimball, K. C. Mcdonald, J. M. Melillo, V. E. Romanovsky, and N. V. Smith. 2006. Importance of recent shifts in soil thermal dynamics on growing season length, productivity, and carbon sequestration in terrestrial high-latitude ecosystems. Global Change Biology 12:731-750.

Flannigan, M. D., I. Campbell, M. Wotton, C. Carcaillet, P. Richard, and Y. Bergeron. 2001. Future fire in Canada's boreal forest: paleoecology results and general circulation model-regional climate model simulations. Canadian Journal of Forest Research 31:854-864.

Foley, J. A., et al. 2005. Global consequences of land use. Science 309:570-574.

Forestry Canada Fire Danger Group. 1992. Development and structure of the Canadian Forest Fire Behavior Prediction System. Information Report ST-X-3. Forestry Canada Science and Sustainable Development Directorate, Ottawa, Ontario, Canada.

Girardin, M. P., and M. Mudelsee. 2008. Past and future changes in Canadian boreal wildfire activity. Ecological Applications 18:391-406.

Gninenko, Y. I., and A. D. Orlinskii. 2002. Dendrolimus sibiricus in the coniferous forests of European Russia at the beginning of the twenty-first century. OEPP/EPPO Bulletin 32:481-483.

Goldammer, J. G., A. Sukhinin, and I. Chisar. 2004. Current situation with fires in Russian Federation: conclusions for expanded international cooperation within UN framework and global programs on fire monitoring and evaluation. Pages 26-55 in Proceedings of International Scientific and Practical Seminar, Khabarovsk, Russia, 9-12 September 2003. [In Russian.] World Bank, Moscow.

Goodale, C. L., et al. 2002. Forest carbon sinks in the Northern Hemisphere. Ecological Applications 12:891-899.

Gordon, C., C. Cooper, C. A. Senior, H. Banks, J. M. Gregory, T. C. Johns, J. F. B. Mitchell, and R. A. Wood. 2000. The 
simulation of SST, sea ice extents and ocean heat transports in a version of the Hadley Centre coupled model without flux adjustments. Climate Dynamics 16:147-168.

Gustafson, E. J., and L. V. Rasmussen. 2002. Assessing the spatial implications of interactions among strategic forest management options using a Windows-based harvest simulator. Computers and Electronics in Agriculture 33:179-196.

Gustafson, E. J., S. R. Shifley, D. J. Mladenoff, H. S. He, and K. K. Nimerfro. 2000. Spatial simulation of forest succession and timber harvesting using LANDIS. Canadian Journal of Forest Research 30:32-43.

Gustafson, E. J., B. R. Sturtevant, and A. Fall. 2006. A collaborative, iterative approach to transfer modeling technology to land managers. Pages 43-64 in A. H. Perera, L. Buse, and T. R. Crow, editors. Forest landscape ecology: transferring knowledge to practice. Cambridge Press, London, UK.

He, H. S., B. E. DeZonia, and D. J. Mladenoff. 2000. An aggregation index (AI) to quantify spatial patterns of landscapes. Landscape Ecology 15:591-601.

IPCC. 2007. Climate change 2007: the physical science basis. Contribution of Working Group I to the Fourth Assessment Report of the Intergovernmental Panel on Climate Change. S. Solomon, D. Qin, M. Manning, Z. Chen, M. Marquis, K. B. Averyt, M. Tignor, and H. L. Miller, editors. Cambridge University Press, Cambridge, UK.

Johnson, E. A., K. Miyanishi, and J. M. Weir. 1998. Wildfires in the western Canadian boreal forest: landscape patterns and ecosystem management. Journal of Vegetation Science 9: 603-610.

Johnson, R. A., and D. W. Wichern. 1992. Applied multivariate statistical analysis. Prentice Hall, Englewood Cliffs, New Jersey, USA.

Kang, S., J. S. Kimball, and S. W. Running. 2006. Simulating effects of fire disturbance and climate change on boreal forest productivity and evapotranspiration. Science of the Total Environment 362:85-102.

Kneeshaw, D. D, and Y. Bergeron. 1998. Canopy gap characteristics and tree replacement in the southeastern boreal forest. Ecology 79:783-794.

Kondakov, Y. 1974. Regularities of the Siberian moth outbreaks. Pages 206-265 in Ecology of forest animal populations. [In Russian.] Nauka, Novosibirsk, Russia.

Kurz, W. A., and M. J. Apps. 1999. A 70-year retrospective analysis of carbon fluxes in the Canadian forest sector. Ecological Applications 9:526-547.

Kurz, W. A., G. Stinson, and G. Rampley. 2008. Could increased boreal forest ecosystem productivity offset carbon losses from increased disturbances? Philosophical Transactions of the Royal Society B 363:2261-2269.

Li, C., M. D. Flannigan, and I. G. W. Corns. 2000. Influence of potential climate change on forest landscape dynamics of west-central Alberta. Canadian Journal of Forest Research 30:1905-1912.

Litkina, L. P. 2003. Forest fire in the Lena-Amga interfluve: influence of climate and ecological changes on permafrost systems. Proceedings of the Second International Conference "The Role of Permafrost Ecosystems in Global Climate Change," 12-17 August 2002, Yakutsk, Russia.

Logan, J. A., J. Regniere, and J. A. Powell. 2003. Assessing impacts of global warming on forest pest dynamics. Frontiers in Ecology and the Environment 1:130-137.

Malevsky-Malevich, S. P., E. K. Molkentin, E. D. Nadyozhina, and O. B. Shklyarevich. 2008. An assessment of potential change in wildfire activity in the Russian boreal forest zone induced by climate warming during the twenty-first century. Climatic Change 86:463-474.

McRae, D. J., et al. 2006. Variability of fire behavior, fire effects, and emissions in Scotch pine forests of central Siberia. Mitigation and Adaptation Strategies for Global Change 11:45-74.
Meleshko, V. P., et al. 2008. Climate of Russia in the XXI century. 3. Future climate changes obtained from an ensemble of the coupled atmosphere-ocean GCM CMIP3. [In Russian.] Meteorology and Hydrology 9:5-22.

Melillo, J. M., A. D. McGuire, D. W. Kicklighter, B. Moore III, C. J. Vorosmarty, and A. L. Schloss. 1993. Global climate change and terrestrial net primary productivity. Nature 363:234-240.

Mladenoff, D. J. 2004. LANDIS and forest landscape models. Ecological Modelling 180:7-19.

Murphy, K. R., and B. Myors. 2003. Statistical power analysis: a simple and general model for traditional and modern hypothesis tests. Second edition. Lawrence Erlbaum Associates, Mahwah, New Jersey, USA.

Nealis, V. G., and J. Regniere. 2004. Insect-host relationships influencing disturbance by the spruce budworm in a boreal mixedwood forest. Canadian Journal of Forest Research 34: $1870-1882$.

Norby, R. J., et al. 2005. Forest response to elevated $\mathrm{CO}_{2}$ is conserved across a broad range of productivity. Proceedings of the National Academy of Sciences 102:18052-18056.

Ollinger, S. V., J. D. Aber, P. B. Reich, and R. J. Freuder. 2002. Interactive effects of nitrogen deposition, tropospheric ozone, elevated $\mathrm{CO}_{2}$ and land use history on the carbon dynamics of northern hardwood forests. Global Change Biology 8:545562.

Ollinger, S. V., and M.-L. Smith. 2005. Net primary production and canopy nitrogen in a temperate forest landscape: an analysis using imaging spectroscopy, modeling and field data. Ecosystems 8:760-778.

Pan, Y., R. Birdsey, J. Hom, K. McCullough, and K. Clark. 2006. Improved estimates of net primary productivity from MODIS satellite data at regional and local scales. Ecological Applications 16:125-132.

Pastor, J., Y. Cohen, and R. Moen. 1999. Generation of spatial patterns in boreal forest landscapes. Ecosystems 2:439-450.

Pastor, J., and W. M. Post. 1988. Response of northern forests to $\mathrm{CO}_{2}$-induced climate change. Nature 334:55-58.

Peltonen, M., A. M. Liebhold, O. N. Bjornstad, and D. W. Williams. 2002. Spatial synchrony in forest insect outbreaks: roles of regional stochasticity and dispersal. Ecology 83: 3120-3129.

Peng, C., and M. J. Apps. 1999. Modelling the response of net primary productivity (NPP) of boreal forest ecosystems to changes in climate and fire disturbance regimes. Ecological Modelling 122:175-193.

Purves, D., and S. Pacala. 2008. Predictive models of forest dynamics. Science 320:1452-1453.

Ravenscroft, C., R. M. Scheller, D. J. Mladenoff, and M. A. White. 2010. Simulating forest restoration in a mixed ownership landscape under climate change. Ecological Applications 20:327-346.

Ripple, W. J., G. A. Bradshaw, and T. A. Spies. 1991. Measuring landscape pattern in the Cascade Range of Oregon, USA. Biological Conservation 57:73-88.

Ruosteenoja, K., T. R. Carter, K. Jylha, and H. Tuomenvirta. 2003. Future climate in world regions: an intercomparison of model-based projections for the new IPCC emissions scenarios. The Finnish Environment 644. Finnish Meteorological Institute, Helsinki, Finland.

Scheller, R. M., and J. B. Domingo. 2006. LANDIS-II core model description. University of Wisconsin, Madison, Wisconsin, USA. 〈http://www.landis-ii.org/documentation/ ModelDescription5.1.pdf $\rangle$

Scheller, R. M., J. B. Domingo, and B. R. Miranda. $2007 a$. LANDIS-II base wind. Version 1.3. Extension user's guide. University of Wisconsin, Madison, Wisconsin, USA. 〈http:// www.landis-ii.org/exts/wind $\rangle$

Scheller, R. M., J. B. Domingo, B. R. Sturtevant, J. S. Williams, A. Rudy, E. J. Gustafson, and D. J. Mladenoff. $2007 b$. Design, development, and application of LANDIS-II, a 
spatial landscape simulation model with flexible spatial and temporal resolution. Ecological Modelling 201:409-419.

Scheller, R. M., and D. J. Mladenoff. 2004. A forest growth and biomass module for a landscape simulation model, LANDIS: design, validation, and application. Ecological Modelling 180:211-229.

Scheller, R. M., and D. J. Mladenoff. 2008. Simulated effects of climate change, tree species migrations, and forest fragmentation on aboveground carbon storage on a forested landscape. Climate Research 36:191-202.

Schmiegelow, F. K. A., and M. Mönkkönen. 2002. Habitat loss and fragmentation in dynamic landscapes: avian perspectives from the boreal forest. Ecological Applications 12:375-389.

Schmullius, C., S. Hese, and S.-I. Team. 2003. SIBERIA-II: sensor systems and data products for greenhouse gas accounting. Pages 1499-1501 in Proceedings of International Geoscience and Remote Sensing Symposium (IGARSS), Toulouse, 21-25 July 2003. IEEE Publications, Piscataway, New Jersey, USA.

Shannon, C. E., and W. Weaver. 1949. The mathematical theory of communication. University of Illinois Press, Urbana, Illinois, USA.

Shinneman, D. J., R. M. Scheller, B. R. Sturtevant, and B. R. Miranda. 2008. LANDIS-II dynamic fuel system. Version 1.0. Extension user guide. University of Wisconsin, Madison, Wisconsin, USA. 〈http://www.landis-ii.org/exts/dynamic_ fire_fuels_system $\rangle$

Shvidenko, A. Z., E. P. Gordov, M. V. Kabanov, V. N. Lykosov, A. A. Onuchin, and E. A. Vaganov. 2007a. Global change in Siberia: realities and expectations. Pages 87-89 in Proceedings of the International Conference and Young Scientists School on Computational Information Technologies for Environmental Sciences (CITES-2007), 20-25 July 2007, Tomsk, Russia.

Shvidenko, A., D. Schepaschenko, and S. Nilsson. 2008. Materials for cognition of productivity of Russian forests. Pages 5-35 in Proceedings of the International Workshop on Sustainable Management of Forests of Russia, 6-7 December 2007. [In Russian.] Krasnoyarsk, Russia.

Shvidenko, A., D. Schepschenko, S. Nilsson, and Y. Bouloui. 2007b. Semi-empirical models for assessing biological productivity of Northern Eurasian forests. Ecological Modelling 204:163-179.
Sofronov, M. A., A. V. Goldammer, A. V. Volokitina, and T. M. Sofronova. 2005. Wildland fire danger. [In Russian.] Institute of Forest, Krasnoyarsk, Russia.

Stephens, S. E., D. N. Koons, J. J. Rotella, and D. W. Willey. 2004. Effects of habitat fragmentation on avian nesting success: a review of the evidence at multiple patial scales. Biological Conservation 115:101-110.

Sturtevant, B. R., E. J. Gustafson, and H. S. He. $2004 a$. Modeling disturbance and succession in forest landscapes using LANDIS: introduction. Ecological Modelling 180:1-5.

Sturtevant, B. R., E. J. Gustafson, V. W. Li, and H. S. He. 2004b. Modeling biological disturbances in LANDIS: a module description and demonstration using spruce budworm. Ecological Modelling 180:153-174.

Sturtevant, B. R., B. R. Miranda, R. M. Scheller, and D. Shinneman. 2008. LANDIS-II dynamic fire system extension. Version 1. User guide. University of Wisconsin, Madison, Wisconsin, USA. 〈http://www.landis-ii.org/exts/dynamic_ fire_fuels_system $\rangle$

Trofymow, J. A., et al. 2002. Rates of litter decomposition over 6 years in Canadian forests: influence of litter quality and climate. Canadian Journal of Forest Research 32:789804.

Vaschuk, L. N., editor. 1992. Background of organization and development of forest management in the Irkutsk region. [In Russian.] Pribaikal State Forest Inventory and Planning Enterprise Irkutsk, Russia.

Vaschuk, L. N., and A. Z. Shvidenko. 2006. Dynamics of forests of the Irkutsk region. [In Russian.] Irkutsk Printing House, Irkutsk, Russia.

Xu, C, G. Z. Gertner, and R. M. Scheller. 2007. Potential effects of interaction between $\mathrm{CO}_{2}$ and temperature on Boundary Water Canoe Area's forest landscape response to global warming. Global Change Biology 13:1469-1483.

Xu, C., G. Z. Gertner, and R. M. Scheller. 2009. Uncertainties in the response of a forest landscape to global climatic change. Global Change Biology 15:116-131.

Yang, J., H. S. He, and E. J. Gustafson. 2004. A hierarchical fire frequency model to simulate temporal patterns of fire regimes in LANDIS. Ecological Modelling 180:119-133.

Yang, J., H. S. He, B. R. Sturtevant, B. R. Miranda, and E. J. Gustafson. 2008. Comparing the effects of fire modeling methods on simulated fire patterns and succession: a case study in the Missouri Ozarks. Canadian Journal of Forest Research 38:1290-1302.

\section{SUPPLEMENT}

LANDIS-II input parameter files used in the simulation experiments for the Siberian study area (Ecological Archives A020-021S1). 